\title{
The Potential of Video Games for Enhancing Teaching History
}

\author{
Ian L. Bass
}

\section{Manchester Metropolitan University, United Kingdom}

\begin{abstract}
This paper reflects on the potential of using video games as a medium to teach medieval history. Building on feedback from students and research around the topic of using video games to teach medieval history, this paper explores how video games can be used to create counterfactual simulations and their potential use as an academic teaching tool.
\end{abstract}

Keywords: Experiential Learning, Higher Education, Real-Time Strategy, Video Games 


\section{Introduction}

Over the past year, I have been considering the implementation of video games in order to teach complex topics on two medieval history modules. The consideration arose from attempting to understand what type of and how much historical and archaeological information can be imparted to a learner interested in a particular time period through interactive mediums. Thinking about the use of video games as a teaching aid has been enhanced in two ways. The first was at the Leeds International Medieval Congress 2019, when Dr John Jenkins, a research associate at the University of York, delivered a paper on 'The Becket Connection - Visualising Medieval Canterbury' and showcased the historically and archaeologically accurate threedimensional rendering of medieval Canterbury, as it was in 1408, giving people the ability to walk around the cityscape in the video game engine Unreal 4 (Dyas and Gibbs, 2020). The second enhancement to this thought came through the online Twitter conference 'The Middle Ages in Modern Games' (2020). The conference delivered on eleven strands of discussion with an international line up of speakers: medieval source material for games; writing history through game mechanics; reenacted and recreating the Middle Ages; historical accuracy and authenticity; games for education and research I and II; medievalist and gaming tropes; gender in medieval video games; medieval games beyond western Europe; magic medicine and religion; and playing the crusades.

It was while I was playing Kingdom Come: Deliverance (Warhorse Studios, 2018), that I truly began to consider the implications of the Visualising Medieval Canterbury project. Kingdom Come, for example, is based on a story set in fifteenth-century Bohemia (now the Czech Republic) during the civil war between Wenceslaus IV 'The Idle' (b. 1361, r. 1363-1419) and his half-brother, Sigismund of Hungary (b. 1368, r. 1387-1437), the sons of Emperor Charles IV (1346-1378). Warhorse Studio's intention was to bring 'real-world locations [...], period-accurate armours and costumes, combat and fencing systems designed in collaboration with the most knowledgeable, skillful swordsmen around, and a story based on actual, historic events' (Kickstarter, 2014 cited in Bostal, 2019: 380). The game takes place over six square miles of accurately rendered real-world landscape between the towns of Sasau and Rattay (Vávra, no date). The creation of a historically and archaeologically accurate video game which correctly portrays medieval life brings the questions of how well can information be imparted with interactive media, and can video games be used to further engage learners in a period which they can only otherwise visualise in their minds when reading scholarship?

The conveyance of historical information through video games is not a new phenomenon, with games such as Medieval II: Total War (The Creative Assembly, 2006), giving the ability to command forces in reasonably accurate simulations of important battles from the Middle Ages-this was further developed in The History Channel's Great Battles: Medieval (2010) which implemented clips from documentaries. This concept of portraying accurate history in the medium of video games is, perhaps, most famously displayed by Ubisoft's video game series, Assassin's Creed (2007- ). In the first ten main games (there are multiple spin-offs, see: Politopoulos et al, 2019: 318) information is generally conveyed through the use of in-

International Journal of Management and Applied Research, 2020, Vol. 7, No. 3 
game encyclopaedias and glossaries, with a general adherence to historical fact in the storyline of the game, not unlike reading an historical novel, making you an active participant in the history that unfolds around you. In the more recent instalments of Assassin's Creed: Origins (Ubisoft, 2017) and Assassin's Creed: Odyssey (Ubisoft, 2018) based in Ptolemaic Egypt (49-47 BC) and during the Peloponnesian War (431$422 \mathrm{BC}$ ) respectively, historical and archaeological information is conveyed through 'Discovery Tour'. It is a system which utilises teams of international experts in order to create an interactive documentary, where players can visit historical sites in game and receive information in audio and video formats.

\section{Student Perceptions and Influences}

In order to understand the potential use of video games as a teaching resource in my own practice, I asked the three seminar groups of undergraduate students I was teaching what types of video games they had played and whether any had influenced their choice to take period specific history modules. I likewise asked about the role of the fictional and fantasy narratives in general, such as Game of Thrones (Martin, 1996- ; produced by Benioff and Weiss, and broadcasted by HBO from 2011 to 2019), on their decision to take modules based on periods of history, such as the Wars of the Roses, since the fantasy series' main inspiration is the Wars (Pavlac, 2017; West, 2019; Weinczok, 2020).

Of the respondents, twelve out of twelve second year undergraduates and twenty-five out of thirty-one third year students had played video games. The same numbers agreed to having played medieval history based games. Ten second years and twenty third years noted that their game playing habits had enhanced their desire to undertake modules based on the periods they had explored virtually. The main games to have inspired module uptake were the Assassin's Creed and Total War (The Creative Assembly, 2000- ), with some other historical games noted, such as Kingdom Come: Deliverance and the real-time strategy game Sid Meier's Civilization V (Fireaxis Games, 2010).

Four out of twelve second years and fifteen out of thirty-one third years likewise articulated that 'triple A' medieval fantasy role-playing games such as The Elder Scrolls V: Skyrim (Bethesda Game Studios, 2011)—loosely based on eighth-century Norse and Viking society—and The Witcher III: Wild Hunt (CD Projekt Red, 2015)— based on Polish history and western folklore (also a book and television series: Sapkowski, 1993-2013; produced by Hissrich and broadcasted by Netflix in 2019) had an impact on their choice. Finally, ten out of twelve second year students claimed that Game of Thrones had a direct impact on their choice of optional third year module to study the Wars of the Roses, and twenty-six out of thirty one third years on the course said that they chose the module as they wanted to explore the 'real history' behind the series. Many of the respondents also noted that the television series Vikings (broadcasted by The History Channel, written by Michael Hirst) also affected their desire to undertake dissertations on Viking Age Britain (for Vikings' historical significance see: Birkett and Dale, 2019; Hardwick and Lister, 2019).

International Journal of Management and Applied Research, 2020, Vol. 7, No. 3 
Overall, from the information provided in this informal discussion with my students, it would appear that the use of video games has generated a substantial interest in their desire to undertake particular optional modules during their undergraduate degrees. As such, there seems to be the significant potential for the use of video games as a method of teaching history in seminars, especially if one were to combine it with the use of counterfactual simulation exercises (Metzger, 2010). This is also enhanced for the second years who undertake an assessment to review the historical accuracy and potential scholarly use of historical novels based on medieval Britain during the period 1066-1317.

The aim of the exercise is that the students will assess and evaluate critically the core historical accuracy at the heart of the novel they choose, and then consider its potential both for generating research interest in the period for the general reader, as well as contemplate the novel's potential as a piece of historical scholarship. It is in this same vein of generating research interest and its potential as historical scholarship that we might also view video games. Those games based in medieval Britain, such as Medieval II: Total War's downloadable content expansion 'Kingdoms' (The Creative Assembly, 2007) — which includes the 'Britannia' campaign based on thirteenthcentury Britain-and Total War Saga: Thrones of Britannia (The Creative Assembly, 2018) offer an alternative form of fictional historical narrative which could be assessed in the same manner as an historical novel.

There are, however, limits to this use. Medieval II's value as an historical source is limited to its define battle scenarios where the player gets to act as an omnipotent general controlling a battle formation against an opposing force controlled by artificial intelligence. In this case skilled players can enter the scenario of the Battle of Hastings in 1066, for example, and engineer alternate history by playing as the English led by King Harold Godwinson (r. 1066) and beat back the forces of William the Bastard, duke of Normandy (later William the Conqueror, r. 1066-1087). On the other hand, this also has its own pedagogic value in the practice of counterfactual history, getting learners to ask the question of 'what if?' which can be a useful learning technique (Taylor, 1994; Brown, 2008; Metzger, 2010; Wainwright, 2014; McCall, 2014; 2016; Spring, 2015). For the Wars of the Roses module there are two games of particular use. The 'hack-and-slash' War of the Roses (Fatshark, 2012) and the 'real-time strategy' game Wars of the Roses (HexWar Games, 2019). Both offer similar experiences to the Total War games, and thus similar drawbacks and benefits.

\section{The Potential of Video Games in Teaching History}

The use of video games and game based learning in higher education institutions is not a new phenomenon and it is useful to provide an analysis here of their wider pedagogic value. Games first became a media through which learning could be facilitated back in the 1970s, though its application declined in the 1980s for other pedagogic methods, only recently coming into 'a renaissance of interest from the distinctively constructivist education theory viewpoint' (Schut, 2007: 232). In fact, this renaissance of interest in the utilisation of video games as a pedagogic resource has manifested itself at my own institution of the Manchester Metropolitan University with the creation in 2016 of the 'Manchester Game Studies Network', which aims to conduct

International Journal of Management and Applied Research, 2020, Vol. 7, No. 3 
interdisciplinary research on the pedagogic value of including scholarship in an interactive format, and to incorporate video games into teaching on undergraduate modules in several university departments (Manchester Metropolitan University, 2020). The use of video games has already been implemented in some ways for history modules, such as in a first year module where there is a seminar on 'Witches \& Witch Hunts' and the students partake in an interactive witch trial through the medium of a video game (Pavlac, 2008).

Unfortunately, because of the current relative lack of using video games to teach historical topics, research and scholarship on the medium is rather diffuse and thus still in the early stages of developing into a field of academic inquiry (Tobias and Fletcher, 2012; Metzger and Paxton, 2016). As noted by Gilbert (2019: 108-109) the 'relative neglect' of the topic is rather strange, especially when one considers that in the United Kingdom, for instance, the video game industry is worth $£ 5.35$ billion (UKIE, 2020), and is the fifth largest video game market in the world (Hoggins, 2018). However, while it is a neglected resource, the small sample of my own students above, though an extremely limited study, demonstrated the fact that a majority of students in seminars will have interacted with video games and it might well have had a large impact on their choice of module uptake.

This is important for the formative impact that gaming and play can have on students' knowledge. As Metzger and Paxton (2016: 2) put it:

An important motivation for our work is the distinct possibility that much of what students today "know" about the past may come not from teachers, textbooks, or tests but from popular-culture media, such as video games. History educators should be aware of how video games may influence young people's thinking about the past that they bring as background to the classroom.

Video games, therefore offer educators unique possibilities to convey their particular topics in an interesting and interactive manner which can be formative on a student's learning experience. Their value as places which can educate as well as challenge perceptions is not to be underestimated. Ubisoft's Far Cry Primal (2016), for example, is set around the end of the Upper Palaeolithic (50,000-12,000 BC) in Europe and utilised experts' knowledge to create a potential version of the language known as Proto-Indo-European (Ubisoft North America, 2016) which can be utilised as a useful tool by linguistics experts for education purposes. On the other hand, challenges can be made to students' perceptions in video games. For instance, Ninja Theory's recent game Hellblade: Senua's Sacrifice (2018) used a fictional story of a Pictish warrioress from eighth-century Orkney (Scotland) journeying to Helheim (the underworld) to save the soul of her dead lover. While simplistic at first, the game takes on a layer of emotional challenge when confronted with the principal subject matter at its core: mental illness. The developers took time to liaise with mental health practitioners, scientists, university experts, the Wellcome Trust, as well as those suffering from mental illness to provide a deep and realistic simulative experience of what it is like to suffer from psychosis and the associated stigma (Fordham and Ball, 2019). Thus video games can have deep learning and social development impacts on learners.

International Journal of Management and Applied Research, 2020, Vol. 7, No. 3 
The idea of using video games in teaching history, then, is significant The story telling parts of video games can be utilised in order to foster social education with learning by reflection, letting the learners become active participants in history rather than simply remaining observers (Gilbert, 2019: 112). Simulations, such as the games already discussed have been described by some, such as Wright-Maley (2015: 67), as 'pedagogically mediated', in that they have been moulded by the experts consulted in order to be used as educational aids; although the definitions between historical game and simulation are debateable and complex (Schut, 2007; McCall, 2016). It is this use as a pedagogic resource which has now resulted in literature identifying frameworks for their use and best practice so that historians can begin the uptake of these games in their teaching (McCall, 2016; Metzger and Paxton, 2016).

There are, however, limitations to the use of video games in seminar settings. Baek (2008) in particular noted that there are six challenges which educators who wish to implement video games into their teaching face, namely: the inflexibility of the curriculum, the negative effects of gaming, students' lack of readiness, lack of supporting materials, fixed class schedules, and limited budgets. Her conclusions noted that it should be games that tailor themselves to the curricula of classes in order that they might fit in with pedagogic practice (Ibid: 671). On the other hand, Taylor in 1994 demonstrated the use of video games in teaching world history, and Wainwright (2014) has taken this further by creating an entire history course concerning history in video games, analysing seven thematic strands present around Sid Meier's Civilization IV (Fireaxis Games, 2005): game mechanics, economics and environment, cultural bias, world systems and world history, determinist and contingency, combat and brutality, and gender.

Others, such as Robison (2013: 578), have even criticised the entire practice of utilising simulation games, such as the Total War series, as a teaching aid because games with player input cannot accurately portray history:

If a battle proceeds differently in a role-playing situation than it did in actuality—which is almost inevitable—students are not learning history. They may acquire some understanding of strategy and tactics, but if, say, Robert E Lee wins the game version of the Battle of Gettysburg, that teaches the student nothing about the real general, the real battle, or the real Civil War.

While this is a valid criticism, it can be combatted. As McCall (2016: 527) articulates: 'Why would a student only have a game to learn from? Why would no other historical materials ranging from historical monographs to primary sources be considered alongside the game?' Indeed, if one placed the video game context within the framework of a well-planned seminar session with the primary and secondary source reading to inform their simulation, then the students have the ability both to learn from the experience of the game in a counterfactual manner, as well as learning from the historical sources which can inform their understanding of the event in which they just participated or presided over.

In this vein, counterfactual history itself has been noted as a useful tool to get students to question and interact with historical conundrums (Metzger, 2010). Constant

International Journal of Management and Applied Research, 2020, Vol. 7, No. 3 
questions historians ask in seminar sessions on medieval British history can, for example, consist of: what would have happened if William the Bastard had not succeeded at the Battle of Hastings in 1066? What if the White Ship disaster never occurred in 1120? What if the Princes in the Tower did not disappear in 1483? There is good reason why counterfactual history books, like those by Timothy Venning (2013a; 2013b; 2013c; 2014), which explore this alternate history exist: precisely because they are interesting paths of scholarly research and can be used to generate debate by those students reading the topics, giving them a broader comprehension of both the short and long term impact of particular events on history. Moreover, Ian Mortimer's Time Traveller's Guide to historical series (2009-18) likewise attempts to replicate in a scholarly sphere what video games already do: they place the reader in the centre of historical events and scenarios, giving the reader an idea of the noise, smells, and feelings if one were transported back in time to a particular period.

It is worth also acknowledging the field of experimental and experiential archaeology which seek to recreate as accurately as possible the techniques and feelings of the past in real world contexts, such as at Guédelon Castle in France (https://www.guedelon.fr/). Guédelon Castle is one of, if not the, biggest experimental and experiential archaeological project in the world, which aims to build a medieval castle from scratch by utilising techniques, dress and the materials available to the masons building in the thirteenth century. Games have also been used to recreate the possibility of walking around archaeological sites, such as Çatalhöyük (Turkey) (Morgan, 2009; Llobera, 2012; Woolford and Dunn, 2013). However, the use of both fields of experimental and experiential archaeology is heavily debated as lines of rigorous academic study (Reynolds, 1999). Video games, therefore, are simply an accessible way in which information can be easily conveyed with potentially deep impacts on students' learning.

\section{Conclusion}

Video games are an engaging medium which could enhance students' learning experience. The games discussed above have much potential for being utilised in seminar and lecture environments on history courses, allowing students to gain an experience of the potential of how the period looked, while also being able to supplement their learning through the use of primary and secondary sources. Moreover, much more use can be made of the potential of video games in creating counterfactual simulations. This, in turn would challenge students to identify the main short and long term impacts of particular events on the period being studied as a whole. There is still necessarily much work to be done to bring video games into modern undergraduate history courses, but the potential certainly needs to be explored more at higher education institutions and in further scholarship.

Acknowledgements: I am grateful to Dr Chrissi Nerantzi for encouraging me to write up these ideas and seek publication, as well as her comments on the present paper.

\section{References}

1. Baek, Y. K. (2008), "What hinders teachers in using computer and vide games in the classroom? Exploring factors inhibiting the uptake of computer and video

International Journal of Management and Applied Research, 2020, Vol. 7, No. 3 
games", CyberPsychology \& Behavior, Vol. 11, No. 6, pp. 665-671. https://doi.org/10.1089/cpb.2008.0127

2. Benioff, D. and Weiss, D. (2011-19), Game of Thrones, [Television] HBO.

3. Bethesda Game Studios (2011), The Elder Scrolls V: Skyrim. Special Edition. Xbox One [Game] Rockville, Maryland: Bethesda Softworks.

4. Birkett, T. and Dale, R. (Eds) (2019), The Vikings Reimagined: Reception, recovery, engagement. Berlin: De Gruyter. https://doi.org/10.1515/9781501513886

5. Bostal, M. (2019), "Medieval video games as reenactment of the past: A look at Kingdom Come Deliverance and its historical claim", in: Sirvent, F., Lloret, R. G. and Ana, R. (Eds), Del siglo XIX al XXI. Tendencias y debates: XIV Congreso de la Asociación de Historia Contemporánea, Universidad de Alicante 20-22 de Septiembre de 2018. Alicente: Biblioteca Virtual Miguel de Cervantes, pp. 380394.

6. Brown, H. J. (2008), Video Games and Education. New York: M. E. Sharpe.

7. CD Projekt Red. (2015), The Witcher III: Wild Hunt. [Game] Ultimate Edition. Xbox One. Warsaw: CD Projekt.

8. Dyas, D. and Gibbs, P. (2020), The Becket Connection - Visualising Medieval Canterbury, [Online] Available from: https://archaeologydataservice.ac.uk/archives/view/becket_ahrb_2020/index.cfm (accessed on 12 March 2020).

9. Fatshark (2012), War of the Roses. Standard Edition. PC. [Game] Stockholm: Paradox Interactive.

10. Fireaxis Games (2005), Sid Meier's Civilization IV. Standard Edition. PC. [Game] Novato, California: $2 \mathrm{~K}$.

11. Fireaxis Games (2010), Sid Meier's Civilization V. Standard Edition. PC. [Game] Novato, California: $2 \mathrm{~K}$.

12. Fordham, J. and Ball, C. (2019), "Framing mental health within digital games: An exploratory case study of Hellblade", JMIR Mental Health, Vol. 6 No. 4, e12432. https://doi.org/10.2196/12432

13. Gilbert, L. (2019), “'Assassin's Creed reminds us that history is human experience': Students' senses of empathy while playing a narrative video game", Theory \& Research in Social Education, Vol. 47, No. 1, pp. 108-137. https://doi.org/10.1080/00933104.2018.1560713

14. Gros, B. (2007), "Digital games in education: The design of games-based learning environments", Journal of Research on Technology in Education, Vol. 40, No. 1, pp. 23-38. https://doi.org/10.1080/15391523.2007.10782494

15. Hardwick, P. and Lister, K. (Eds) (2019), Vikings and the Vikings: Essays on television's History Channel series. Jefferson, North Carolina: McFarland \& Company Inc.

16. HexWar Games (2019), Wars of the Roses. Standard Edition. PC. [Game] Elgin: HexWar Games.

International Journal of Management and Applied Research, 2020, Vol. 7, No. 3 
17. Hirst, M. (Writer) (2020), Vikings (2013-20), [Television Series] The History Channel.

18. Hissrich, L. S. (2019), The Witcher [Television] Netflix.

19. Hoggins, T. (2018), "Games industry contributes nearly £3bn to UK Economy", The Telegraph, 9 October 2018 [Online] Available from: https://www.telegraph.co.uk/technology/2018/10/08/games-industry-contributesnearly-3bn-uk-economy/ (accessed on 20 April 2020).

20. Llobera, M. (2012), "Life on a pixel: Challenges in the development of digital methods within an 'interpretive' landscape archaeology framework', Journal of Archaeological Method and Theory, Vol. 19, No. 4, pp. 495-509. https://doi.org/10.1007/s10816-012-9139-2

21. Manchester Metropolitan University (2020), Manchester Game Studies Network, [Online] Available from: https://www.manchestergamestudies.org/ (accessed on 15 April 2020).

22. Martin, G. R. R. (1996- ), A Song of Ice and Fire [Book series] London: HarperCollins Publishers.

23. McCall, J. (2014), "Simulation games and the study of the past: Classroom guidelines", In: Kee, K. (Ed). Pastplay: Teaching and learning history with technology. Ann Arbor, Michigan: University of Michigan, pp. 228-253.

24. McCall, J. (2016), “Teaching history with digital historical games: An introduction to the field and best practices", Simulation \& Gaming, Vol. 47, No. 4, pp. 517-542. https://doi.org/10.1177/1046878116646693

25. Metzger, S. A. (2010), "Magna Carta: Teaching medieval topics for historical significance", The History Teacher, Vol. 43, No. 3, pp. 345-356.

26. Metzger, S. A. and Paxton, R. J. (2016), "Gaming history: A framework for what video games teach about the past", Theory \& Research in Social Education, Vol. 44, No. 4, pp. 532-564. https://doi.org/10.1080/00933104.2016.1208596

27. Morgan, C. L. (2009), "(Re)Building Çatalhöyük: Changing virtual reality in archaeology", Archaeologies: Journal of the World Archaeological Congress, Vol. 5, No. 3, pp. 468-487. https://doi.org/10.1007/s11759-009-9113-0

28. Mortimer, I. (2009), The Time Traveller's Guide to Medieval England: A handbook for visitors to the fourteenth century. London: Vintage.

29. Mortimer, I. (2013), The Time Traveller's Guide to Elizabethan England. London: Vintage.

30. Mortimer, I. (2018), The Time Traveller's Guide to Restoration Britain: Life in the age of Samuel Pepys, Isaac Newton and the Great Fire of London. London: Vintage.

31. Ninja Theory (2018), Hellblade: Senua's Sacrifice. Standard Edition. Xbox One. [Game] Cambridge: Ninja Theory.

32. Pavlac, B. A. (2004), A Witch Hunt: Germany 1628, [Online] Available from: http://departments.kings.edu/womens_history/witch/hunt/index.html (accessed on 15 April 2020).

International Journal of Management and Applied Research, 2020, Vol. 7, No. 3 
33. Pavlac, B. A. (2017), Game of Thrones versus History: Written in blood. Hoboken, New Jersey: John Wiley and Sons Inc. https://doi.org/10.1002/9781119249450

34. Politopoulos, A., Mol, A. A. A., Boom, K. H. J. and Ariese, C. E. (2019), “'History is our playground': Action and authenticity in Assassin's Creed: Odyssey", Advances in Archaeological Practice, Vol. 7, No. 3, pp. 317-323. https://doi.org/10.1017/aap.2019.30

35. Reynolds, P. J. (1999), "The nature of experiment in archaeology", In Coles, J. M. and Harding, A. F. (Eds). Experiment and Design: Archaeological studies in honour of John Coles. Oxford: Oxbow Books Ltd, pp. 156-162.

36. Robison, W. B. (2013), "Stimulation, not simulation: An alternate approach to history teaching games", The History Teacher, Vol. 46, No. 4, pp. 577-588.

37. Sapkowski, A. (1993-2013), The Witcher. [Book series] London: Gollancz.

38. Schut, K. (2007), "Strategic simulations and out past: The bias of computer games in the presentation of history", Games and Culture, Vol. 2, No. 3, pp. 213-235. https://doi.org/10.1177/1555412007306202

39. Spring, D. (2015), "Gaming history: computer and video games as historical scholarship", Rethinking History: The Journal of Theory and Practice, Vol. 19, No. 2, pp. 207-221. https://doi.org/10.1080/13642529.2014.973714

40. Taylor, T. (1994), "Using the simulation "Civilization" in a world history course", History Microcomputer Review, Vol. 10, No. 1, pp. 11-16.

41. The Creative Assembly (2006), Medieval II: Total War. Standard Edition. PC. [Game] Tokyo: Sega.

42. The Creative Assembly (2007), 'Kingdoms.' In Medieval II: Total War. Definitive Edition. PC [Game] Tokyo: Sega.

43. The Creative Assembly (2018), Total War Saga: Thrones of Britannia. Standard Edition. PC. [Game] Tokyo: Sega.

44. The Middle Ages in Modern Games (2020), Middle Ages in Modern Games Twitter Conference: 30 Jun - 3 Jul 2020 [Online] Available from: https://twitter.com/MidAgesModGames (accessed on 3 July 2020).

45. Tobias, S. and Fletcher, J. D. (2015), "Reflections on 'a review of trends in serious gaming”, Review of Educational Research, Vol. 82, No. 2, pp. 233-237. https://doi.org/10.3102/0034654312450190

46. Ubisoft North America (2016), Far Cry Primal Behind the Scenes 3 - Characters and Language, [Video] Available from: https://www.youtube.com/watch?v=UTZHKZpYgKA\&feature=emb_title (accessed on 22 April 2020).

47. Ubisoft (2007), Assassin's Creed. Standard Edition. Xbox 360. [Game] Montreal: Ubisoft.

48. Ubisoft (2016), Far Cry Primal. Standard Edition. Xbox One. [Game] Montreal: Ubisoft.

International Journal of Management and Applied Research, 2020, Vol. 7, No. 3 
49. Ubisoft (2017), Assassin's Creed: Origins. Gold Edition. Xbox One. [Game] Montreal: Ubisoft.

50. Ubisoft (2018), Assassin's Creed: Odyssey. Omega Edition. Xbox One. [Game] Quebec: Ubisoft.

51. UKIE (2019), UK Consumer Games Market Valuation, [Online] Available from: https://ukiepedia.ukie.org.uk/index.php/2019_UK_Consumer_Games_Market_Val uation (accessed on 20 April 2020).

52. Vávra, D. (no date), "Game vs. fact: Looking at places from Kingdom Come: Deliverance in real life", DOUPE [Online] Available from: https://doupe.zive.cz/clanek/hra-vs-skutecnost-podivejte-se-na-mista-z-kingdomcome-deliverance-v-realu (accessed on 1 April 2020).

53. Venning, T. (2013a), An Alternative History of Britain: The Anglo-Saxon Age. Barnsley: Pen \& Sword Military.

54. Venning, T. (2013b), An Alternative History of Britain: The Hundred Years' War. Barnsley: Pen \& Sword Military.

55. Venning, T. (2013c), An Alternative History of Britain: The War of the Roses. Barnsley: Pen \& Sword Military.

56. Venning, T. (2014), An Alternative History of Britain: Normans and early Plantagenets. Barnsley: Pen \& Sword Military.

57. Wainwright, A. M. (2014), "Teaching historical theory through video games", The History Teacher, Vol. 47, No. 4, pp. 579-612.

58. War Drum Studios and Slitherine. (2010) Great Battles: Medieval. Standard Edition. Xbox 360. [Game] New York: The History Channel.

59. Warhorse Studios (2018) Kingdom Come: Deliverance. Special Edition. Xbox One. [Game] Höfen: Deep Silver.

60. Weinczok, D. C. (2020), The History behind Game of Thrones: The north remembers. Barnsley: Pen and Sword Books Limited.

61. West, E. (2019), Iron, Fire and Ice: The real history that inspired Game of Thrones. New York: Skyhorse Publishing.

62. Woolford, K. and Dunn, S. (2013), "Experimental archaeology and games: Challenges of inhabiting virtual heritage", Journal on Computing and Cultural Heritage, Vol. 6, No. 4, article 16. http://doi.org/10.1145/2532630.2532632

63. Wright-Maley, C. (2015), "Beyond the 'Babel problem': Defining simulations for the social studies", The Journal of Social Studies Research, Vol. 39, No. 2, pp. 6377. https://doi.org/10.1016/j.jssr.2014.10.001

International Journal of Management and Applied Research, 2020, Vol. 7, No. 3 